\title{
1 Chickpea: In the Backdrop Note
}

Physical availability, economic accessibility and risks related to either availability or access of food are most important criteria to diminish the hunger and malnutrition, and avail food security for all into practical dimensions (von Braun et al., 1992). Food security has been defined as "access by all people at all time to enough food for an active and healthy life” (World Bank, 1986; Kharkwal and Shu, 2009). Although, several world food summits were organized during past decades, the number of hungry people keeps increasing and now exceeds one billion (Swaminathan, 2010). One of the ways to acheive food security is through focused and practical work by reviving and expanding research strategies and activities beyond traditional stars of food grains such as wheat, rice, barley etc. to the crops like pulses. The production rate of pulse crops will have and/or is to play an important role in curbing and declining the food insecurity and malnutrition problems in developing countries like India for better future.

\subsection{General Account of Pulses and Chickpea}

Pulse crops, commonly known as food grain legumes, are grown in wide range of agroclimatic zones and form an integral part of vegetarian diet of Indian sub-continent, thus, contributing around $25-28 \%$ of the total global production (Goyal et al., 2011). Certain unique characteristics of pulse crops like high protein content ( 2 to 3 times more than the cereals), nitrogen fixing ability, soil ameliorative properties and ability to thrive better under harsh conditions make pulses an essential component of sustainable agriculture particularly in dry land areas (Singh, 1987; Wani et al., 2011a). In addition, the Indian population is mainly dependent upon pulses for fulfilling their protein requirement because of high cost associated to animal based proteins and vegetarian food habits (Yadav, 1991).

Developing countries, such as India, can take a rightful pride in attaining selfsufficiency in the production of food grains but most of them have miserably failed in case of pulses because their production could not keep pace with the population growth. Indian population is growing at a rapid rate, and hence stagnation in pulse production has meant a severe decline in the per capita pulse availability. Per capita pulses consumption over the years has come down from $60.7 \mathrm{~g} /$ day in 1951 to $37.0 \mathrm{~g} /$ day in 2009 (DES, 2010). A solution to the problem of declining per capita availability has to, therefore, come from a rapid improvement in indigenous production levels. While efforts have been geared up to bring additional area under pulses, more important is to increase the production by exploiting yield potential of existing varieties through genetic manipulations. The estimates at the end of first decade of $21^{\text {st }}$ century (for 2009-2010) indicate that the pulses occupy an area of 23.35 million hectares in India and produce 14.60 million tonnes with an average yield of $625 \mathrm{~kg} / \mathrm{ha}$ 
(Fig. 1.1; for latest data information's log onto http://agricoop.nic.in/Agristatistics.htm). The average growth rate of pulses production during this period was 3.64 percent, which is far below the required growth rate to meet domestic requirements during the last one and half decade, 1995-2010 (DES, 2010). The non-availability of high yielding varieties is a major constraint in achieving higher pulse productivity. Nonsynchronous maturity, long duration, flower drop and presence of different kinds of natural (like valconic eruptions, tsunami, forest fire etc.), and man-created (waste products, pollution, sewage as outcome of various industries, thermal power plants, etc.) anthropogenic pressures are other problems associated which hinders the production of high yielding varieties of major pulses.

Chickpea (Cicer arietinum L.), also known as Bengal gram, Gram or Chana (Hindi), is an important ancient annual grain legume used in human diet. Chickpea is a winter (rabi) season crop and requires cool climate for its growth and high temperature for maturity. Chickpea performs well when grown on sandy/loam soils associated to good drainage system.

Based upon seed size and colour, chickpea is classified as "kabuli type", or "macrosperma" and "desi type” or "microsperma". Kabuli type chickpea seed is bold and has thin seed coat ranging from white to pale cream in colour. On the other hand, desi type chickpea seed is small compared to the kabuli type chickpea and has thicker seed coat ranging in colour from brown to yellow. The kabuli type chickpea is believed to have developed from desi type chickpea through natural mutation and selection (Moreno and Cubero, 1978; Hawtin and Singh, 1980; Salimath et al., 1984; Gil and Cubero, 1993). Toker (2009) reported that kabuli chickpea could have originated from spontaneous mutants of $C$. reticulatum.

Chickpea is the second largest grown food legume. It ranks third among pulses and $119^{\text {th }}$ among the grain crops of the world (Gaur et al., 2008; Kulthe and Kothekar, 2011). India leads the list of chickpea producing countries in area, as well as production. In India, chickpea is grown in the drier areas as they are best suited for its production. Chickpea producing states in India are Madhya Pradesh, Maharashtra, Rajasthan, Uttar Pradesh and Karnataka. Data on production, area harvested, and yield quantity of chickpea in India for the first decade of $21^{\text {st }}$ century (since 2001-2010) are given in Fig. 1.2. The area of chickpea under cultivation in India is 8.21 million hectares with an annual production of 7.35 million tonnes in 2009-2010. The average yield is $895 \mathrm{~kg} / \mathrm{ha}$ and average growth rate production was 4.58 percent (DES, 2010), which is low for this crop because it engages the large area under its cultivation as compared to other pulse crops and is not sufficient to meet the growing demand. For latest data information's log onto http://agricoop.nic.in/Agristatistics.htm)

In order to break the yield plateau in chickpea, efforts are needed to develop high yielding varieties with appropriate growth habit (ICAR-ICARDA, 2010). Genetic enhancement for yield, synchronization in maturity, tolerance to major biotic and abiotic stresses and increasing the nutrient composition of the crop to large extent is a major concern due to less genetic variability in chickpea. The possibility offered 
by mutagenic agents to induce new genetic variation is, therefore, of extreme interest and importance. Since chickpea is a self-pollinating crop, mutation breeding could be rewarding for broadening the genetic base of total plant yield, yield contributing traits and other important traits like nutritive composition.

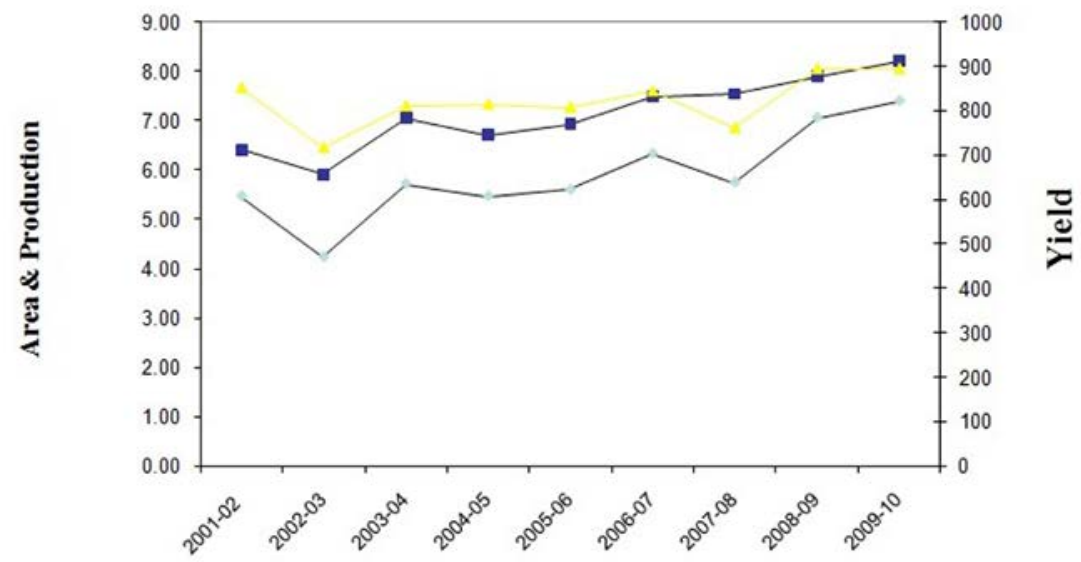

\section{Area $\left[\mathrm{m} . \mathrm{ha}^{-1}\right]$}

Fig. 1.1: National trends in area, production and yield of pulses. (Source: Directorate of Economics and Statistics (DES), Department of Agriculture and Cooperation, Ministry of Agriculture, Government of India)

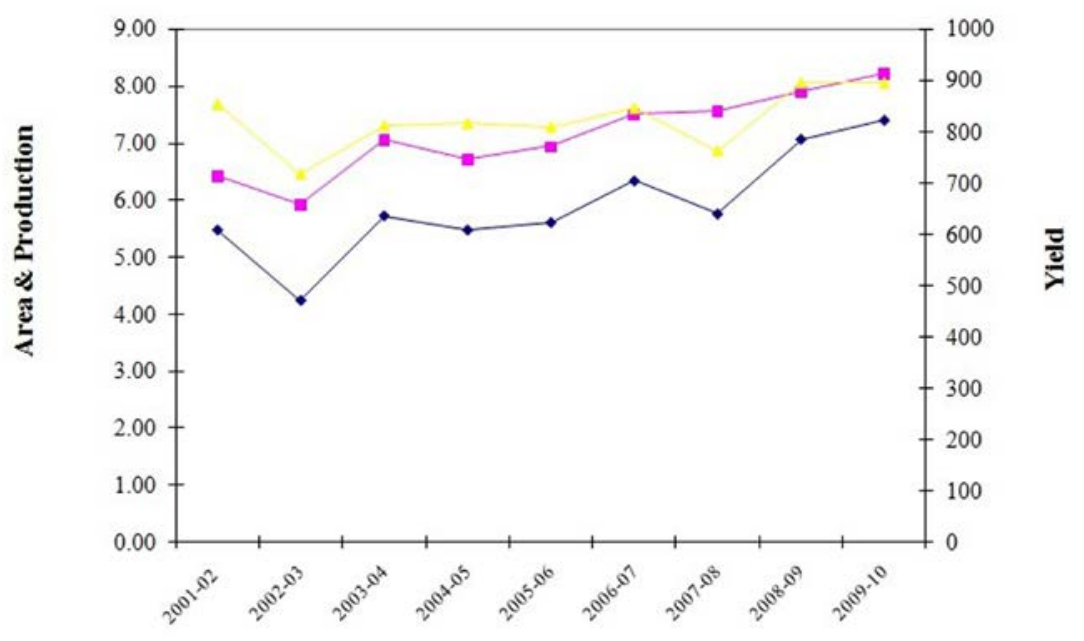

- Area $\left[\mathrm{m} . \mathrm{ha}^{-1}\right] \quad$-- Production [ mt] Yield [kg. ha- $\left.{ }^{1}\right]$

Fig. 1.2: National trends in area, production and yield of chickpea. (Source: Directorate of Economics and Statistics (DES), Department of Agriculture and Cooperation, Ministry of Agriculture, Government of India) 


\subsection{Botanical Description of Chickpea}

The genus Cicer belongs to the family Fabaceae. The genus Cicer consists of 44 species, including 35 perennial and eight annual wild species and one the domesticated chickpea, Cicer arietinum L. (van der Maesen et al., 2007; Toker, 2009). The plant has a deep tap-root with well defined root-nodules. Stem is mostly erect and green. Leaves are stipulate and imparipinnately compound, usually small leaflets in each leaf, which are arranged on a rachis with a small petiole. Glandular hairs cover all external surfaces of the plant, with the exception of corolla. Flowers are pedicellate bisexual with papilionaceous corolla, borne singly in axillary racemes. The staminal column is diadelphous (10 stamens with an arrangement of $9+1$ ). Ovary is monocarpellary, unilocular, 1-2 ovules and superior with a terminal slightly bent style and blunt stigma. Pistil and anthers usually remain inside the keel. Pollination takes place before the opening of the bud. Thus self-pollination is the rule (Auckland and van der Maesen, 1980; Singh and Ibrahim, 1990; Toker et al., 2006). The fruit of chickpea is the inflated pod with 1-2 seeds. The surfaces of the seeds are wrinkled or smooth and the germination is hypogeal in chickpea.

\subsection{Economic Importance of Chickpea}

Chickpea seeds are very rich source of carbohydrates, proteins, fats and many other essential nutritive components, which are consumed by humans. In fact, chickpea has one of the highest nutritional compositions of any dry edible legume and does not contain any specific major antinutritional factors (CGKB, 2010; Malikarjuna et al., 2011) and could be a useful source of dietary nutrients, especially in malnourished populations (Ibrikci et al., 2003). The nutritional composition of chickpea is given in Table 1.1. Chickpea seeds are eaten fresh as green vegetables, parched, fried, roasted, broiled as snack food, sweets and condiments and their flour is used in soup/salads and to make bread.

Among the food legumes, chickpea is the most hypocholesteremic agent as the germinated chickpea is effective in controlling cholesterol level (Geervani, 1991). Glandular secretion of the leaves, stems and pods consists of malic and oxalic acids, which are collected and used for medical purposes, particularly in India. Medicinal applications include use for aphrodisiac, bronchitis, catarrh, cutamenia, cholera, constipation, diarrhoea, dyspepsia, flatulence, snakebite, sunstroke, and warts (Muehlbauer and Tullu, 1997). Seeds of chickpea are considered antibilious and also yield $21 \%$ starch, which is suitable for textile sizing, giving a light finish to silk, wool and cotton cloth (Duke, 1981). 
Table 1.1: Nutritional composition of mature chickpea seeds (value per $100 \mathrm{~g}$ edible portion).

\begin{tabular}{llllll}
\hline Energy (kcal) & 364 & & & & \\
\hline $\begin{array}{l}\text { Proximates (g) } \\
\text { Carbohydrate }\end{array}$ & 60.65 & Protein & 19.30 & Fiber & 17.4 \\
Water & 11.53 & Fat & 6.04 & Ash & 2.48 \\
Amino acids (g) & & & & Arginine & 1.819 \\
Glutamic acid & 3.375 & Aspartic acid & 2.270 & Phenylalanine & 1.034 \\
Leucine & 1.374 & Lysine & 1.291 & Isoleucine & 0.828 \\
Serine & 0.973 & Alanine & 0.828 & Proline & 0.797 \\
Valine & 0.809 & Glycine & 0.803 & Tyrosine & 0.479 \\
Threonine & 0.716 & Histidine & 0.531 & Tryptophan & 0.185 \\
Cystine & 0.259 & Methionine & 0.253 & & \\
Vitamins (mg) & & & & Pantothenic acid & 1.588 \\
Choline & 95.2 & Ascorbic acid & 4.0 & Vitamin B & 0.535 \\
Niacin & 1.541 & Vitamin E & 0.82 & & \\
Thiamine & 0.477 & Riboflavin & 0.212 & & 115 \\
Minerals (mg) & & & & & Magnesium \\
Potassium & 875 & Phosphorus & 366 & Iron & 6.24 \\
Calcium & 105 & Sodium & 24 & Copper & 0.847 \\
Zinc & 3.43 & Manganese & 2.204 & &
\end{tabular}

Source: USDA National Nutrient Database for Standard Reference, Release 23 (2010)

\subsection{Origin, Biosystematics and Cytogenetics}

The domesticated chickpea (Cicer arietinum L.) is one of the seven Neolithic founder crops (other crops being einkorn wheat, emmer wheat, barley, lentil, pea and bitter vetch) and the wild progenitors of all of them are found together in the core area of the Fertile Crescent, a place near the upper reaches of the Tigris and Euphrates rivers in present-day southeastern Turkey/northern Syria (Lev-Yadun et al., 2000). It is also believed that cultivated chickpea have originated at least 7000 years ago in south eastern Turkey and adjoining areas of Iraq, Iran and former Soviet Union (Ramanujam, 1976) with Cicer reticulatum L. being the wild progenitor (Ladizinsky and Alder, 1976). Some believe that C. reticulatum is sub-species of $C$. arietinum L. (Singh and Singh, 1997). Earlier botanists had postulated several different origins. De Candolle (1883) traced the origin of chickpea to an area south of Caucasus and in the north of Persia. Vavilov (1926) recognized the Mediterranean, Central Asia and Indian regions as the probable centers of origin of chickpea. There is linguistic evidence that the large seeded chickpea reached India via Afghan capital, Kabul, about two 
centuries ago and acquired a name in Hindi as "Kabuli Chana" (van der Maesen, 1972). The small seeded chickpea is called "desi" (local) and these denominations are commonly used to distinguish the two main groups of the cultivars. The earliest record of chickpea in India is from Atranji Khera in Uttar Pradesh and this dates back to 2000 B.C. (Chowdhury et al., 1970). It was introduced in Peninsular India probably between 500 and 300 B.C. (Vishnu-Mitre, 1974).

The genus Cicer belongs to the family Fabaceae and the tribe Cicereae (Iruela et al., 2002). However, some argue that it belongs to tribe Vicieae (Singh et al., 1997). The genus consists of 44 species of which 35 are perennial and nine are annual (van der Maesen et al., 2007; Toker, 2009), including the cultivated one.

Chickpea (C. arietinum L.) is a diploid and self-pollinating annual pulse crop known to have somatic chromosome number to be $2 \mathrm{n}=16$ (Singh and Singh, 1997; Bharadwaj et al., 2006), with genome size $1 \mathrm{C}=740 \mathrm{Mbp}$ (million base pair). There are reports of $2 \mathrm{n}=14$ chromosome number, but presumably such plants of Cicer are rare and may not be able to maintain themselves in nature (Singh et al., 1997).

\subsection{Case Studies}

Keeping in view the socio-economic and nutritional importance of chickpea, a selffertilized crop, and its role in food security, various studies were encased for the present monographic work in upcoming chapters (chapter numbers 3, 4, 5, 6, 7 and 8 ) in order to understand the genetic basis of quantitative traits in chickpea (Cicer arietinum $\mathrm{L}$.). The detailed background information and their comparative discussion to the estimated case study results has been well explained. Overall, an attempt has been made through specialized chapters of case studies to evaluate quantitative traits in $M_{1}$ to $M_{3}$ generations following mutagenesis with gamma rays, ethylmethane sulphonate (EMS) and their combination treatments in two varieties of chickpea viz., Pusa- 256 and BG-1053. 